\title{
Subsidized Fertilizer Distribution Method in Zimbabwe
}

\author{
Charles, Munyanyi $\cdot$ Hwang, Hancheol* \\ The Graduate School of International Development and Cooperation, Hankyong National University \\ *Dept. of Bioresource \& Rural Systems Engineering, Hankyong National University
}

\section{짐바브웨의 보조금 비료의 효율적 배분 방법}

\author{
찰스 무냐니 - 황한철
}

한경대학교 국제개발협력대학원 • ${ }^{*}$ 한경대학교 지역자원시스템공학과

\begin{abstract}
요 약 : 아프리카 사하라 이남지역의 농업 정책가들은 빈농을 위한 보조금 비료가 효율적으로 배분되지 않고 있는 것을 매 우 중요한 문제라 인식하고 있다. 즉 보조금 비료가 시장가격으로 비료를 구입할 수 있는 부유한 농가에게 돌아가는 등의 문제점이 발생하고 있다. 결국 빈농을 위한 보조금 비료 프로그램의 원래 목적을 크게 손상시키고 있는 셈이다. 짐바브웨 정부가 시도하고 있는 보조금 비료 프로그램은 소농을 대상으로 배분하고 있으며, 주로 빈농이 대부분인 지역을 그 대상으 로 한다. 본 연구는 사하라 이남지역 일부 국가의 사례연구와 짐바브웨 농가를 대상으로 한 설문조사를 바탕으로 수행되었 다. 주요 논점은 1)소농을 위한 보조금 비료가 현지 시장가격으로 구입할 수 있는 부농가로 흘러가고 있는지, 2)짐바브웨 농가들의 보조금 비료 배분 프로그램에 대한 인식은 어떠한지 등이다. 짐바브웨 카도모 지역에서 무작위로 100 가구를 선정 하여 설문조사를 실시하고 분석하였다. 가구당 수입과 보조금 비료의 접근과는 무관한 것으로 나타닜고, 현지 시장에서 비 료를 사는 것과 가구당 수입과는 유의미한 것으로 나타났다 $(\mathrm{p}=0.0037)$. 이는 보조금 비료의 수혜자가 현지 시장에서 비료를 살 수 있는 능력을 가지고 있다는 것을 보여 주고 있다. 가구당 수입과 보조금 비료 혜택을 보지 못한 채 비료 없이 작물 을 재배하는 것과의 관계를 분석한 결과 유의한 수준을 보이고 있다 $(\mathrm{p}=0.040)$. 이는 보조금 비료의 획득에 실패했을 때 그 농가들은 결국 비료 없이 농사를 지을 것이라는 것을 보여주는 것이다. 이 프로그램에 대한 많은 농가들의 일반적인 인식 은 부농이나 영향력 있는 농가가 빈농에 비해 혜택을 더 보고 있다고 생각한다. 이러한 인식을 가능케 하는 이유는 많은 농가들이 수혜자 선정 과정에 관여하지 못하기 때문에 결국 부농을 위한 프로그램이라는 의심을 가지게 된다는 것이다.
\end{abstract}

핵심용어 : 보조금 비료, 소농, 농민의 인식, 효율적 배분, 수혜자

\section{Introduction}

There is considerable evidence showing that agricultural growth has played a critical role in poverty reducing growth around the world (Dorward et al., 2004).For countries to achieve agricultural growth there is need for improvements in agricultural technology. Improvements in agricultural technologies are achieved through the introduction of improved inputs such as fertilizers (Pender et al., 2004, IFDC, 2003). Some governments in

Corresponding author : Hwang, Hancheol

Tel. : 031-670-5133

E-mail : hwang@hknu.ac.kr
Sub-Saharan Africa have over the years tried to avail subsidized fertilizers to the low income vulnerable households by deliberately creating a criteria which targets them so that they benefit from such a program. A well targeted subsidized fertilizer program besides promoting agricultural productivity and food security for the poor will not destabilize the ability of better off farmers to purchase the fertilizer on commercial terms(Minde I et al., 2008). The entry point of this research is to investigate the subsidized fertilizers distribution method in Zimbabwe. Zimbabwe economy is largely agrarian. Access to fertilizers to enhance yield is often a problem for the marginalized farmers especially in Zimbabwe and other Sub-Saharan 
Africa countries. Resource poor farmers despite government commitments to have them access subsidized fertilizers are generally not getting their dues they continue to be food insecure (Amoaka, 2003) and seek for food handouts from government yet a substantial amount is being spent by government in subsidizing fertilizers for their benefit. In Zimbabwe during the 2008/2009 and 2009/2010 season the government availed subsidized fertilizers to the poor, the program was targeted at those farming sectors where smallholder farmers are located (FAO/World food program Crop and food Security Assessment mission to Zimbabwe, August 2010). The assumption being that it's where the poor farmers are located.

\section{Problem statement}

When subsidized fertilizers are not properly targeted they tend to benefit the wrong class of farmers thereby negating the benefits associated with such programs. The intention of this research is to analyze the Zimbabwe subsidized fertilizer distribution methods. This will be carried out by comparing the Zimbabwe program to other almost similar programs is sub-Saharan Africa countries. The Zimbabwean program will then be evaluated in order to establish who its beneficiaries are. The paper will then seek to establish how the program in Zimbabwe can be improved in order to achieve its intended goals.

\section{Review of Literature}

Farmers in Sub-Saharan Africa (SSA) still use far much less fertilizers compared to other regions of the world. The average intensity of fertilizer use throughout SSA is roughly 9 kilograms per hectare. This is far much less than elsewhere as the figure below shows. Compared to other developing continents Africa ranks the least in terms of fertilizer use. This has an impact on food security in the continent. One of the most important reasons why fertilizer use rates are so low in Africa is that fertilizer costs in Africa are higher than in Latin America and Asia. (Kherallah et al., 2002).The higher costs becomes more prohibitive to fertilizer users especially the underprivileged who cannot afford to buy the fertilizer at the official market price and thus will opt not to use the fertilizers in their land unless if provided at an affordable price or distributed freely.

1) Comparison of change in the use of Nitrogen fertilizer/arable land, in different regions from 1962-2007

Sub-Saharan still lags far below Western Europe and South East Asia in terms of Nitrogen fertilizer use. By 1985 Europe was utilizing about 170kgs of Nitrogen fertilizer compared to a low level of less than10kgs per hectare for Sub-Saharan Africa.

Expects in agriculture perceive use of contemporary inputs especially fertilizer as solution to agricultural productivity. Fertilizer generates high proceeds and the impressive growth in agricultural yields in Asia and the stagnation of yields in Africa can chiefly be explained by increase in fertilizer use in Asia and continued low use in Africa (Morris et al., 2007).

Based on the above preposition Ellis, 1992 and Sachs, 2004 have strongly advocated for fertilizer subsidies. Fertilizer subsidies especially targeted to the poor have several other benefits associated with it. Some of the benefits are countering effects of low producer price, reduction of income disparity and helping in maintaining and restoring soil fertility. Malawi, Zambia and Nigeria have over the years implemented targeted fertilizer subsidies with varying degrees of outcome. The process in all the three countries involved coming up with identification criteria that aims at filtering out farmers that are relatively better off such that the poor farmers are given priority to the commodity.

2) Malawi fertilizer subsidy program

Malawi has since the year 2005 involved in a massive fertilizer subsidy program in order to increase productivity in agriculture and boost food security in the country. The program was aimed at providing coupons to poor vulnerable household so that they will be able to purchase subsidized fertilizers. This program provides an interesting study on how targeting of the fertilizer was carried out in order to reach the poor households. The Ministry of agriculture and food security (MoAFS) attempted to come with a criterion to try and target the poor households. Despite these set of criterion Dorward et al.,(2008) found out that a significant amount of the fertilizers went to the less poor during the 2006/2007 agricultural seasons. Holden and Lunduka, (2010) found evidence that there was an 
illegal market for some of the coupons for subsidized fertilizers. This was connected to the fact that the list of potential beneficiaries could have been inflated resulting in many non existing households receiving some coupons. The other problem which was encountered was that there was no proper records as to the number of coupons that had been printed and distributed (Logistic Unit, 2009).A study carried out by Stein and Rodney, (2010) in six districts of Malawi also found out that the majority of coupons that were in the unofficial market came from other sources other than the households who had received them from the program suggesting that some of the coupons were leaking out of the official system. The study also revealed the fact that livestock-rich households, households with higher consumption needs and male headed rather than female headed households were the households that were likely to receive the coupons for subsidized fertilizers indicating that although the program was targeted at the poor households generally the arrangement appear to support the more affluent households. Although the Malawi subsidized program was faced with various challenges it must be stated though that outstanding progress were recorded in maize production. The harvest recorded during the subsidy era surpassed the National requirements of around 2.4 million tones.

The noted success to the Malawi program can be attributed to its implementation modalities which had the following positive attributes.

The case of Malawi fertilizer subsidy program shows that in order for the programs to improve the incomes and food security of the smallholder farmers the programs should be designed and implemented so as to target households with little ability to afford the fertilizers (Minde et al., 2008).The challenge then is to be able to recognize the not so poor from the poor.

\section{3) The Zambian Program}

After the Government of Zambia had realized that only $20 \%$ of the small-scale farmers had access to fertilizers it instituted the Fertilizer Support Program (FSP) in 2002.The program was put in place in order to militate against food insecurity and poverty both at household and national level. (Reichhuber et al., 2010).Under the plan the fertilizer was to be supplied by private fertilizer companies at district level. Local transporters were then to carry the fertilizer closer to the beneficiaries. The benefiting farmers were supposed to be organized into cooperatives. The Zambian program also displayed some shortfalls in terms of the targeting and selection of beneficiaries. Findings from the study showed that the beneficiary selection was arbitrary and non-transparent. Furthermore the selection criteria was all encompassing such that all smallholder farmers were eligible to benefit from the program and the objectives of the program was unclear (Zambia Impact Assessment of the Fertilizer program).

4) Background to fertilizer subsidies in Zimbabwe

After attaining independence in 1980 the major policy focus by the government on fertilizers was to promote the use of fertilizers by small holder farmers by providing credit to smallholder farmers through the Agricultural Finance Corporation (AFC). The early to late 1990s saw the International Monetary Fund (IMF) and the World

Table 1 Summary of the implementation modalities of the Malawi subsidy program

\begin{tabular}{c|l}
\hline Implementation modalities & \multicolumn{1}{c}{ Activities } \\
\hline Beneficiary identification criteria & The local registration was done by local people themselves using a bottom up strategy \\
\hline Use of voucher system & $\begin{array}{l}\text { Vouchers were used to identify beneficiaries and also for purchasing subsidized } \\
\text { fertilizers }\end{array}$ \\
\hline Project cycle management & $\begin{array}{l}\text { Involvement of Ministry of Agriculture local structures. Private sector was involved in } \\
\text { transportation and sale of inputs. There was also involvement of civil society and } \\
\text { cooperating partners }\end{array}$ \\
\hline Funding & $\begin{array}{l}\text { Local resources from government was used and government had autonomy in } \\
\text { management of program }\end{array}$ \\
\hline
\end{tabular}

Source: Compiled by Author based on presentation made by MoAFS 


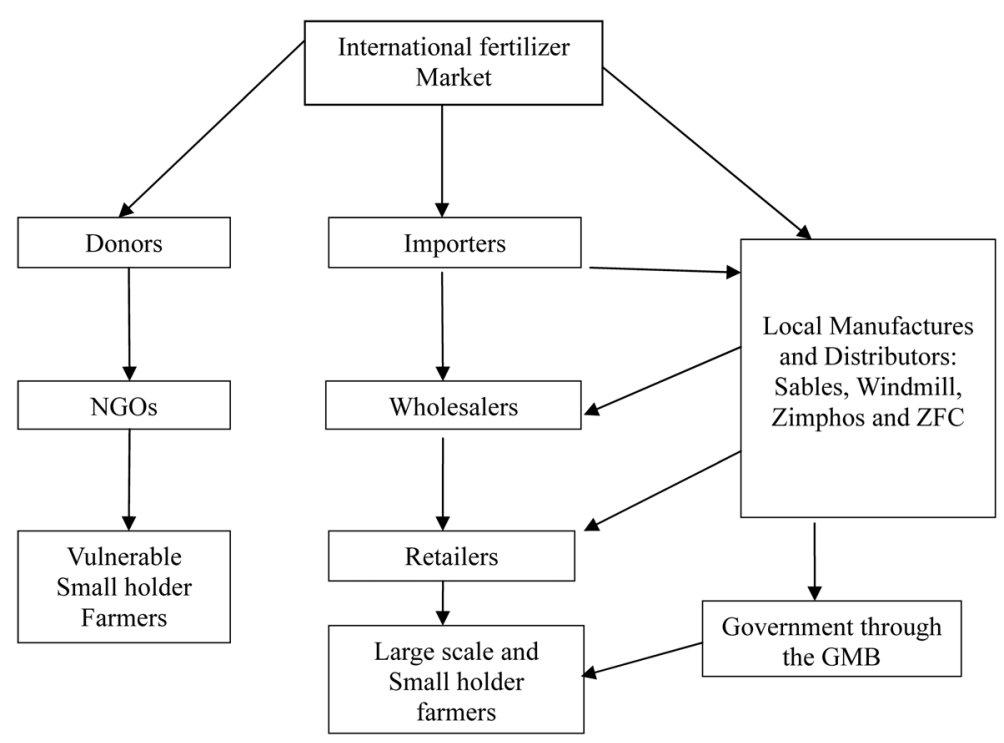

Figure 1 Schematic diagram showing how farmers accessed fertilizer in

Zimbabwe in 2008-2010 agricultural seasons.

Source: Adapted from Minde et al., 2010

Bank encouraging the government of Zimbabwe to embark on Economic Structural Adjustment Program (ESAP) (Rohrbach et al., 2004). This resulted in the coming in of seven companies in the fertilizer market .These were selling fertilizers directly to all farmers including the small holder farmers (Rukuni et al., 2006).

The fertilizer situation in the country, after the year 2000 resulted in the government starting to distribute subsidized fertilizers to farmers in order to stem out food insecurity problems. Government started to sideline the commercial farmers especially the large scale and A2 farmers starting from the 2005/2006 and 2006/2007 season. This saw the distribution of subsidized fertilizers being mainly targeted at the more vulnerable and less endowed communal and old resettlement farmers. Commercial farmers were expected to purchase fertilizers at the market by using cash or to seek loans from banks (Govere I et al., 2009). The subsidized fertilizer was being distributed though the Grain Marketing Board (GMB) a state agency. For the 2008/2009 and the 2009/2010 season the subsidized fertilizer was being sold at \$7/bag (FAO/WFP Crop and food Security Assessment mission to Zimbabwe, August 2010). The market price of the same bag was $\$ 27 /$ bag. At the same time the GMB was also selling fertilizers to other farmers who could afford at the market price of $\$ 27 / \mathrm{bag}$. This second facility was designed for commercial farmers including smallholder farmers who had the money to purchase the fertilizer.GMB is a government owned parastatal whose main function, within its main purpose of ensuring the country's food security by being the country maize strategic reserve store. After the land reform of 2000 the GMB has also been involved in the sale and distribution of agricultural inputs such as fertilizers to farmers on behalf of the government. The involvement of government though the Grain Marketing Board in distribution of inputs especially fertilizer was based on the argument that the Land reform program which the government had undertaken since year 2000 had changed the arrangement of the country agricultural sector too hastily for private providers of agricultural marketing and support services to fine-tune their operations to accordingly serve the new realities (Govere I et al., 2009).

\section{Methodology}

\section{Site selection}

Muzvezve 11 area in Kadoma district of Zimbabwe was selected for this research because it represents an area with 
some farmers who were entitled to acquire subsidized fertilizers from the Grain Marketing Board. This is because it falls under the old resettlement scheme which is one of the smallholder sector targeted by the government to benefit from the subsidized fertilizer program. The area also has farmers with varying socio-economic status thereby making it ideal for this type of study.

\section{Sampling procedure}

In coming up with the study area purposive sampling was used. Purposive sampling is a process whereby the researcher selects a sample based on experience or knowledge of the group to be sampled. The technique of purposive sampling is suitable for a social science research because it focuses directly to an area intended for the study.

\section{Selection of Interviewees}

For selecting the households where the questionnaire is to be administered simple random sampling was used. This was based on the premise that the selected study site has households that have varied socio economic characteristics. Muzvezve 11 resettlement scheme has 13 villages. These are named as village 1 to village 13 respectively. Four villages were randomly selected and then from the selected villages 25 households from each village were then randomly selected. The selection of the 25 households per village was done using the systematic random sampling method using the village registers.

\section{Data Collection}

This study applied the personnel interview type of survey questionnaire. This was done by using the Shona language which is the main language used in Muzvezve 11 area.

\section{The household questionnaire}

The questionnaires designed for this research seek to capture the household's per capita incomes and access to subsidized fertilizers. The coping strategies which households employ when they fail to get the subsidized fertilizers were also captured. Lickert scale test was also employed to elicit the views of the households on why they think the generally poor farmers are not acquiring subsidized fertilizers.

\section{Review of other targeted subsidized programs in Malawi and Zambia}

Malawi and Zambia have undertaken subsidized fertilizer distributions with varying degrees of success. Experiences in how such programs were done will also be used so as to derive lessons for the Zimbabwean case.

\section{Data Analysis}

Data were sorted, coded, summarized and analyzed by using the SAS computer software. The Likert scale was also used to come up with the general perceptions of the households towards the program. Based on the objectives of the study, descriptive statistics and the Chi- Square test were then used.

\section{Research Findings and discussions}

This chapter presents the results obtained in the study and there after the discussion.

\section{Land ownership, age and gender character- istics of the study site}

The results show that $93 \%$ of households own the plots, $67 \%$ of the sampled households are more than 45 years and $80 \%$ of the households are male. Most households in the study site are headed by males with female headed households only constituting $20 \%$ of the total respondents.

The majority of the of the respondents in the study site were owners of their respective plots(93\%).This therefore means there is autonomy in decisions making especially in the acquisition of subsidized fertilizers unlike non plot owners who in most cases have to consult since they don't have the required papers. In order to acquire subsidized fertilizers from GMB there is need for a farmer to have a letter confirming that is the legitimate owner of the piece of land. Most households' heads are above 45years and 
Table 2 Land ownership, age and gender characteristics of the study site

\begin{tabular}{c|c|c|c}
\hline Characteristic & Variable & Frequency & Percentage \\
\hline \multirow{2}{*}{ Plot Ownership } & Owner & 93 & 93 \\
\cline { 2 - 4 } & Non-Owner & 7 & 7 \\
\multirow{2}{*}{ Age in years } & Less than 20 & 32 & 32 \\
\cline { 2 - 4 } & More than 45 & 67 & 67 \\
\cline { 2 - 4 } & Male & 80 & 80 \\
\cline { 2 - 4 } & Female & 20 & 20 \\
\hline \multirow{2}{*}{ Gender } & & & \\
\hline
\end{tabular}

Source: Research data 2011

usually with such an age they are confined to farming and most unlikely to be involved in other non farming activities such as gold panning which is prevalent among the youth in and around the area.

\section{Per capita income of sampled households}

$80 \%$ of the sampled households had a per capita income of one dollar or less per day whilst $20 \%$ of the households earned a per capita income of more than one US dollar per day.

The bulk of the households in the study site (80\%) were found to earn a per capita income of one Us dollar or less per day. The fact that the bulk of the households are having a per capita income of less than one US dollar per day may indicate that the idea by the government to target this sector as one of the beneficiaries of subsidized fertilizers is justified since most of them are having incomes that are below the poverty datum line. The targeting of fertilizer subsidies to this sector can then be justified considering that most household have a low per capita income.

When the relationship between per capita income and acquiring of fertilizer by households was investigated, the relationship between the two variables was insignificant, $\mathrm{X}^{2}$ $=0.93, \mathrm{p}=0.3$, displaying the fact that per capita income had no significant relationship to acquiring subsidized fertilizers. In Malawi Holden and Lunduka, (2010) found out that most coupons for subsidized fertilizers went to those households who were livestock rich and had a generally higher consumption levels. In Zambia the subsidized fertilizer was generally captured by households with a good asset base (ZIAFP).

\section{Household awareness to the program}

On average for the two seasons understudy $84 \%$ of the respondents were aware of the fertilizer subsidy program whilst $16 \%$ were not aware of the program.

House hold awareness to the program is important in that it determines if access to subsidized fertilizers is due to lack of information or to other factors other than this. The majority of the sampled households were aware of such a program. This means that for most respondents the decision not to acquire the fertilizers is mainly due to other reasons other than lack of information. There is need though for the awareness program to also cater for the other households who professed ignorance to the program.

\section{Households perception towards the program}

1) Perception towards the overall objective of the program

The bulk of the respondents were in agreement that availing subsidized fertilizers to the poor was a welcome

Table 3 Socio-economic status of the households

\begin{tabular}{c|c|c|c}
\hline Socio-economic Indicator & Variable & Frequency & Percentage \\
\hline \multirow{2}{*}{ Per capita income(USS) } & One or less/day & 80 & 80 \\
\cline { 2 - 4 } & More than One/day & 20 & 20 \\
\hline
\end{tabular}

Source: Research data 2011 
Table 4 Household awareness to the program

\begin{tabular}{c|c|c|c}
\hline Season & Variable & Frequency & Percentage \\
\hline \multirow{2}{*}{$2008 /$} & Aware of program & 87 & 87 \\
2009 & Not aware of program & 13 & 13 \\
\cline { 2 - 4 } $2009 /$ & Aware of program & 81 & 81 \\
\cline { 2 - 4 } 2010 & Not aware of program & 19 & 84 \\
\hline \multirow{2}{*}{ Both seasons } & Aware of program & 84 & 16 \\
\cline { 2 - 4 } & Not aware of program & 16 & \\
\hline
\end{tabular}

Source: Research data 2011

Table 5 Nobility of the program

\begin{tabular}{c|c|c}
\hline Variable & Likert scale value & Frequency \\
\hline Strongly agree & 5 & 70 \\
\hline Agree & 4 & 0 \\
\hline Undecided & 3 & 3 \\
\hline Disagree & 2 & 6 \\
\hline Strongly disagree & 1 & \\
\hline Average Likert scale value & \multicolumn{2}{|c}{4.5} \\
\hline
\end{tabular}

Source: Research Data 2011

development (average Likert scale value $=4.5$ ).

A good perception by households is important in that when the program is being implemented households have positive attitudes it and are likely to freely participate in such a program.

\section{2) Characteristics of beneficiaries of subsidized fertilizers}

Interviewed households were of the perception that being a productive farmer and being poor is not given priority when beneficiaries of subsidized fertilizers are selected. Rather farmers were of the view that being rich and influential is a factor which may determine access to farmers.

According to farmers the subsidy program is not taking cognizant of factors such as being rich and being poor as a priority yet the main objective of the program is to increase food security to the poor households. Most households in the study site were in agreement that being influential is a characteristic that determines having access to subsidized fertilizer (average Likert scale value =4.9). The other characteristic that was regarded by most farmers as being unique to accessing the fertilizer was that of being relatively well off (rich) with an average Likert scale value of 4.4. Most households strongly disagreed to the notion that being poor is considered as a characteristic in acquiring subsidized fertilizers. The findings also show that being a productive farmer is not a characteristic that is considered in acquiring the subsidized fertilizer. Farmers

Table 6 Characteristics of beneficiaries of subsidized fertilizers

\begin{tabular}{|c|c|c|c|c|c|c|c|c|}
\hline \multirow[b]{2}{*}{ Characteristic/Response } & \multicolumn{2}{|c|}{ Must be productive } & \multicolumn{2}{|c|}{ Must be rich } & \multicolumn{2}{|c|}{ Must be influential } & \multicolumn{2}{|c|}{ Must be poor } \\
\hline & $\begin{array}{c}\text { Likert } \\
\text { scale value }\end{array}$ & Freq & $\begin{array}{c}\text { Likert } \\
\text { scale value }\end{array}$ & Freq & $\begin{array}{c}\text { Likert } \\
\text { scale value }\end{array}$ & Freq & $\begin{array}{c}\text { Likert } \\
\text { scale value }\end{array}$ & Freq \\
\hline Strongly agree & 5 & 0 & 5 & 81 & 5 & 89 & 5 & 3 \\
\hline Agree & 4 & 0 & 4 & 6 & 4 & 10 & 4 & 9 \\
\hline Undecided & 3 & 0 & 3 & 0 & 3 & 0 & 3 & 0 \\
\hline Disagree & 2 & 79 & 2 & 0 & 2 & 0 & 2 & 17 \\
\hline Strongly disagree & 1 & 19 & 1 & 10 & 1 & 0 & 1 & 67 \\
\hline Average Likert scale value & \multicolumn{2}{|l|}{1.8} & \multicolumn{2}{|l|}{4.4} & \multicolumn{2}{|l|}{4.9} & \multicolumn{2}{|l|}{1.5} \\
\hline
\end{tabular}

Source Research data 2011 
Charles, Munyanyi $\cdot$ Hwang, Hancheol

Table 7 Perception on why the poor may be failing to access subsidized fertilizers

\begin{tabular}{|c|c|c|c|c|c|c|}
\hline \multirow[b]{2}{*}{ Characteristic and response } & \multicolumn{2}{|c|}{ Price still expensive } & \multicolumn{2}{|c|}{ Transportation problem } & \multicolumn{2}{|c|}{ The poor not prioritized } \\
\hline & $\begin{array}{c}\text { Likert scale } \\
\text { value }\end{array}$ & Freq & $\begin{array}{c}\text { Likert } \\
\text { scale value }\end{array}$ & Freq & $\begin{array}{c}\text { Likert scale } \\
\text { value }\end{array}$ & Freq \\
\hline Strongly agree & 5 & 31 & 5 & 88 & 5 & 68 \\
\hline Agree & 4 & 58 & 4 & 12 & 4 & 11 \\
\hline Undecided & 3 & 0 & 3 & 0 & 3 & 5 \\
\hline Disagree & 2 & 11 & 2 & 0 & 2 & 16 \\
\hline Strongly disagree & 1 & 0 & 1 & 0 & 1 & 0 \\
\hline Average Likert scale value & \multicolumn{2}{|c|}{4.1} & \multicolumn{2}{|c|}{4.9} & \multicolumn{2}{|c|}{4.3} \\
\hline
\end{tabular}

have the perception that the relatively well off farmers are benefiting from government fertilizer program. This though was not confirmed by this research. In Malawi Stein, $\mathrm{H}$ and Rodney L found out that $17.3 \%$ of household considered being poor as a characteristic in acquiring fertilizer whilst $34.3 \%$ believed that being wealthier is the important characteristic. Salimona, (2007) in a study in Nigeria found out that $82.1 \%$ of farmers believed that being rich and influential determines access to subsidized fertilizers. The study also showed that $83.3 \%$ of farmers disagreed that being a farmer is a factor determining access to fertilizers which implies that even those who were not farmers were acquiring these subsidized fertilizers. The subsidized fertilizers program in Zimbabwe has no set criteria for targeting the poor and this result in most farmers having the perception that it's being accessed by the more affluent. A bottom up beneficiary identification criteria will go a long way towards removing this negative perception since most farmers will have been involved in selection of beneficiary and will be aware of the beneficiaries of the program. Non- involvement of farmers in the selection process of beneficiaries can result in suspicion as to who is accessing these fertilizers. When coming up with a list of beneficiaries it's important to include within the criteria parameters such as being productive although resource poor.

3) Household's perception on why they think the poor may not be acquiring government subsidized fertilizers

Sampled households listed the following in order of importance as factors which are disadvantaging the ability of the poor to access subsidized fertilizers i) Problems of transporting the fertilizers from GMB(average Likert value=4.9) ii)Lack of a deliberate priority towards the poor(average Likert value $=4.3$ ). iii) The price of subsidized fertilizer may still be expensive to the poor households (average Likert scale value $=4.1$ ).

Most of the sampled households cited the problem of transporting the subsidized fertilizer from GMB as a factor that contributes to them not even going to GMB to try and access the subsidized fertilizer. The study also cited lack of prioritizing the poor as a second factor that contributes to the poor not getting the fertilizers. The third factor that was also mentioned by the respondents was that of pricing. Some households have the impression that the subsidized price is still expensive for them .A look at the per capita income of the households somehow supports this augment. The results shows that in order for the underprivileged farmers to fully benefit from the government subsidized fertilizer program the issue of its price, targeting mechanism for the poor and availing it to farmers at nearby locations need to be addressed. Some farmers may not be attempting to benefit from such a program because they think that the system has already eliminated them. The issue of transportation problem can be addressed by the introduction of private sector and rural agro dealers.

\section{Access to subsidized fertilizers by households in the study}

For the two seasons which were under study $20 \%$ of households managed to access the subsidized fertilizers whilst $80 \%$ failed to access it. 
Table 8 Access to subsidized fertilizers by households under the study

\begin{tabular}{c|c|c|c}
\hline Season & Variable & Frequency & Percentage \\
\hline \multirow{2}{*}{$2008 /$} & Acquired the Fertilizer & 21 & 21 \\
\cline { 2 - 4 } 2009 & Did not Acquire the Fertilizer & 79 & 79 \\
\hline $2009 /$ & Acquired the Fertilizer & 19 & 19 \\
2010 & Did not Acquire the Fertilizer & 81 & 81 \\
\cline { 2 - 4 } & Acquired the Fertilizer & 20 & 20 \\
\cline { 2 - 4 } & Doth seasons & 80 & 80 \\
\hline
\end{tabular}

Source: Research data 2011

The study shows that the fertilizers targeted to this farming sector, overall is not adequate to cover all farmers. Hence some farmers will be excluded by such a program. For the sampled respondents only $20 \%$ managed to acquire the subsidized fertilizers. This findings were different from studies carried out in Malawi districts during the 2008/2009 season were households acquisition of the subsidized fertilizers were 75.3 percent. This shows some shortcomings of the program in terms of satisfying the needs of the poor households in the Zimbabwe case study. The generally low quantities of the availed fertilizers to the study site could be one of the reasons why farmers speculate that some other class of rich and influential farmers may be acquiring the fertilizers. Above all the government should try and avail more fertilizers to the poor households such that a higher percentage of the households in this sector acquire the commodity. . It's still important though for the government to investigate if the low quantities of fertilizers supplied to the smallholder sector are not due to other factors such as leakage and diversion.

\section{Uniformity of subsidized fertilizer acquired by} households (was the quantity of subsidized fertilizers issued to farmers' uniform?)
Most farming households showed that the package of subsidized fertilizers availed to farmers were not uniform (average Likert scale value $=2.3$ ). This effectively means that there is variability in terms of quantity of subsidized fertilizers availed to households.

Farming households are not getting a homogeneous supply of subsidized fertilizers. Some households get a larger package than others. Examination of the uniformity of the fertilizers that beneficiary households were acquiring show that in most instances those benefiting are not entitled to standardized quantities.65.6\% of the respondents confirmed that the fertilizer that they access was not uniform across the households. This shows that there is no criterion to equally allocate the fertilizers or if it's there it's simply being ignored. The government should address the issue of standardized quantities. Giving standard quantities of fertilizers to households will not only eliminate bribery in the distribution process but will also results in the program covering more farming households.

\section{Timeliness in availing subsidized fertilizers}

All farming households interviewed in the survey were in agreement that the time when subsidized fertilizer is availed at GMB was not timely. Timeliness in availing fertilizers is a necessary prerequisite in achieving desired

Table 9 Uniformity of subsidized fertilizers acquired by households

\begin{tabular}{c|c|c}
\hline Variable & Likert scale value & Frequency \\
\hline Strongly agree & 5 & 16 \\
\hline Agree & 4 & 18 \\
\hline Undecided & 3 & 0 \\
\hline Disagree & 2 & 9 \\
\hline Strongly disagree & 1 & 57 \\
\hline Average Likert scale value & & 2.3 \\
\hline
\end{tabular}

Source: Research Data 2011 
results. A delay in getting the fertilizer will compromise productivity since there is a positive correlation between yield and time of planting. . In order for subsidized fertilizer to play its significant role which among other things is to increasing food security it must be availed to farmers on time. The results from the study shows that all $(100 \%)$ of the respondents confirmed that the subsidized fertilizer was not availed timely thereby negating the intending effects. This finding were in harmony with studies by Salimonu, (2007) in Nigeria were it was found that 90.4 percent of households reported that the fertilizers were not supplied on time. Studies by Holden and Lunduka, (2010) for the 2008/2009 Malawi program showed an improvement in the time that the fertilizer was supplied with 67.5percent of households agreeing that the fertilizer was supplied on time.

\section{Follow up to the program}

$75 \%$ of the households alluded to the fact that there is no follow up made to assess how the subsidy program has progressed whilst $25 \%$ of respondents said that there is a trail up on the program. Follow ups to such programs are important in that they come up with lessons for future improvement and also minimize leakage of the commodity. The bulk of the households in the study area confirmed that there was no follow up to the program. The fact that most households know that nobody follows the program means that the program may be open to abuse. Some households may acquire the fertilizers and opt to sell it to other farmers at a better price. Officials involved in the distribution process may also take advantage of this and divert the product to where they can get returns. Holden and Lunduka (2010) found that in two districts of Malawi the list of potential household beneficiaries was deliberately inflated by 1.3 million households. This implies that they could have been non existing households benefiting from such programs.

\section{Coping strategy by households.}

A Chi-square test was performed to examine the relationship between household per capita income and coping strategy variables and the results found are described below.

1) Per capita income and purchasing of fertilizers on the market

There was a positive significant relationship between household per capita income and ability to purchase subsidized fertilizers on the open $\operatorname{market}\left(\mathrm{X}^{2}=8.41\right.$, $\mathrm{p}=0.0037)$. This effectively mean that some households can purchase fertilizers on the market if these are not availed to them.

2) Per capita income and planting without fertilizers

A Chi-square test carried out between per capita incomes and planting without inorganic fertilizers showed a positive relationship $\left(\mathrm{X}^{2}=4.21, \mathrm{p}=0.040\right)$.

Table 10 Per capita incomes and purchasing of fertilizer on open market

\begin{tabular}{c|c|c}
\hline & \multicolumn{2}{|c}{ Income } \\
\multicolumn{1}{c|}{ Coping strategy } & 1US\$or less/day & More than 1US\$/day \\
\hline$\%$ of households buying market priced fertilizer & 30.4 & 63.6 \\
\hline$\left(\mathrm{X}^{2}=8.41, \mathrm{p}=0.0037\right)$ & \\
Source: Research data 2011 &
\end{tabular}

Table 11 Per capita income and planting without fertilizers

\begin{tabular}{c|c|c}
\hline & \multicolumn{2}{|c}{ Income } \\
\hline \multicolumn{1}{c|}{ Coping strategy } & 1US\$or less/day & More than 1US\$/day \\
\hline$\%$ of households planting without fertilizers & 26.6 & 4.5 \\
\hline $\begin{array}{l}\left.\mathrm{X}^{2}=4.21, \mathrm{p}=0.040\right) \\
\text { Source research data } 2011\end{array}$ & &
\end{tabular}


When the Chi- square test was performed on per capita income and the coping strategy of buying fertilizers on the open market was found to be significant $\left(X^{2}=8.41\right.$, $\mathrm{p}=0.0037)$.From this it can be predicted that some households who are acquiring subsidized fertilizer have the capacity to purchase the subsidized fertilizers on the market. These are the households which the government should try and filter out of the subsidy program. The Chisquare test carried out between per capita income and the coping strategy of planting without fertilizers was also significant $\left(\mathrm{X}^{2}=4.21, \mathrm{p}=0.04\right)$. These are the households who when they fail to get the subsidized fertilizers they plant without the fertilizers and should be targeted by the government subsidy program. The results are in harmony with the study carried out by Salimonu, (2007) in Nigeria who found out that $28.6 \%$ of the marginalized farmers revealed that as a coping strategy they cannot afford to buy fertilizer at an extra cost after failing to acquire the subsidized fertilizer. The findings suggest that a sizeable number of farmers who are accessing the subsidized fertilizer can afford to purchase fertilizer on the open market when they fail to get the subsidized fertilizer. This reasoning has two pronged effects. Firstly the subsidized fertilizer will have a net effect of disrupting the open market fertilizer distribution system since some buyers who are able to buy the fertilizer at the market rate price will not do so since they are benefiting from the subsidized fertilizer. Secondly the poor who, when they fail to acquire the subsidized fertilizer have no option are being displaced from acquiring the subsidized fertilizer by those who can afford, thereby negating the arguments associated with availing subsidized fertilizer to the poor. A bottom up beneficiary identification criteria should be designed in such a way that those who can purchase fertilizers are excluded from the scarce subsidized fertilizers. The Chi- square test relationship between per capita income and use of manure and reduction of area planted was found to be insignificant. Use of livestock is the second available option that most households use after failing to acquire subsidized fertilizers. The government should actually reinforce on this noble alternative by encouraging farmers who have the livestock manure to even try and substitute inorganic fertilizers with livestock manure and avoid using livestock manure as a coping strategy.

\section{Conclusion and recommendations}

This study was aimed at investigating the Zimbabwean approach in distribution of subsidized fertilizers. The Zimbabwean subsidized fertilizer distribution methods of targeting the poor has resulted in most farmers within the targeted smallholder sector having the perception that it is the rich and influential who are benefited from such a program. This study could not confirm this view. The possible reasons to such views could be that the fertilizers being distributed are inadequate to cover most farmers and also the criterion for identifying the beneficiary is disorganized. A bottom up identification criteria will be ideal in such a scenario. The study also revealed that farmers with generally high per capita income are likely to purchase fertilizers from the open market as substitute for subsidized fertilizers whereas farmers with low income levels are likely to plant without fertilizers when they fail to acquire the subsidized fertilizers. The government should therefore design the subsidized fertilizers program such that they filter out farmers who can buy the fertilizers and concentrate on those who when they fail to get the fertilizers they tend to plant without any fertilizers. Distribution of targeted subsidized fertilizers requires strong government commitment so that it does not affect the commercial fertilizer market in the country and also ability to face challenges associated with misuse and leakages from the program. Generally most households in the study have a perception that fertilizers are being acquired by the more affluent household. This perception could be due the fact that there is no top down approach to the distribution process. There is need to involve the households in the selection process so that the process is transparent. Studies in other countries have revealed that the fertilizer subsidy programs usually encounter the problems of leakages. The government of Zimbabwe can minimize this demise by applying appropriate control measures which range from printing vouchers with security marks and also ongoing audit and monitoring of the program. In order to militate against the effects of subsidized fertilizer unavailability by poor households due to unaffordable prices, the government should try and avail these fertilizers during the period when most households are still having cash. The period usually is just after the peak marketing period. This study only focused on per capita income as a measure of 
socioeconomic status. It will be more conclusive if other socioeconomic status variables such as household assets are factored in. The study will also produce better results if it was replicated in other smallholder sectors of Zimbabwe and in more than one district.

\section{References}

1. Amoaka, K.Y., 2003, "Harnessing technologies for sustainable development in Africa" 5th Annual Peter Doherty Distinguished Lecture, International livestock research Institute, Addis Ababa, Ethiopia (http://www.uneca.org/eca_resources/speeches/amoako/20 03/041003lecture ilri.htm).

2. Dorward, A., Chirwa, E., Kelly, V., Jayne, T., Slater, R., and Boughton, D., 2008, Evaluation of the 2006/07 Agricultural Input subsidy Programme, Malawi, Final Report. A Study undertaken for the Ministry of Agriculture and Food Security, Malawi, DFID, USAID and Future Agricultures Consortium, pp.9-14.

3. Dorward A, Fan,S., Kydd, J., Lofgren, H., Morrison, J., Poulton, C., Rao, N., Smith, L., Tchale, H, Thorat, S., et al, 2004, Rethinking Agricultural Policies for Pro-Poor Growth. Natural resources Perspectives 94. ODI, London, September, pp.1-4.

4. Ellis, F., 1992, Agricultural Policies in Developing Countries. Cambridge: Cambridge University Press, pp.357.

5. FAO/WFP, 2010, Crop and Food Security Assessment Mission to Zimbabwe, pp.7-11.

6. Govere I., Foti, R., Mutandwa, E., Mashingaidze, A.B., and Bhebhe, E, 2009, Policy Perspectives on the Role of Government in the Distribution of Agricultural Inputs to farmers: Lessons from Zimbabwe.

7. Holden, S., and Lunduka R., 2010, Impact of the Fertilizer Subsidy Program in Malawi: Targeting, Household Perceptions and Preferences. Noragric Report No.54. Department of International Environment and Development studies, Nor agric Norwegian University of life Sciences, UMB.

8. IFDC, 2003, Input Subsidies and Agricultural Development: Issues and Options for Developing and
Transitional Economies. International Fertilizer Development Center, Muscle Shoals, AL, pp.29.

9. Isaac, M., Jayne, T.S., Crawford, E., Ariga, J., and Govereh, J., 2008, Promoting Fertilizer Use in Africa: Current Issues and Empirical Evidence from Malawi, Zambia, and Kenya. ReSaKSS Working Paper No 13

10. Kherallah, M., Delgado,C., Gabre-Madhin, E., Minot, N., and Johnson, M., 2002, Reforming Agricultural Markets in Africa. Baltimore, MD: IFPRI/Johns Hopkins University Press, pp.370.

11. Logistic Unit, 2009, Final Report. Implementation of Agricultural Input Subsidy Programme 2008/2009. Logistic Unit.

12. Minde, I., Mazvimavi, J., Kizito, M., and Ndlovu,C., 2010, Supply and Demand trends for Fertilizers in Zimbabwe: 1930 to date: Key drivers and lessons learnt. Contributed Paper presented at the Joint 3rd African Association of Agricultural Economists (AAAE) and 48th Agricultural Economists Association of South Africa (AEASA) Conference, Cape Town, South Africa, September 19-23 2010, pp.16.

13. Pender, J., Nkonya, E., and Rosegrant, M. (2004). Soil Fertility and Fertilizer Subsidies in Sub Saharan Africa: Issues and Recommendations. Power Point presentation. IFPRI, Washington, DC, pp.69.

14. Rohrbach., D, Charters, R., and Nyagweta, J., 2004, Guidelines for Agricultural Relief Programs in Zimbabwe. ICRISAT Box 776, Bulawayo, Zimbabwe, pp.70.

15. Sachs, J. D., 2004, The case for Fertilizer Subsidies for Subsistence Farmers. Working Paper, the Earth Institute at Columbia University, pp.1-8.

16. Salimonu, K. K., 2007, Attitude to risk in Resource Allocation among food Crop farmers in Osun state, Nigeria. PHD thesis, Agricultural Economics department, University of Ibadan, Ibadan.

접 수 일: (2011년 10월 18일)

수 정 일: (1차: 2011년 12월 2일, 2차: 12월 20일)

게재확정일: (2011년 12월 20일)

- 3 인 익명 심사필 